\title{
DAMPAK NEGATIF ADIKSI PENGGUNAAN SMARTPHONE TERHADAP ASPEK-ASPEK AKADEMIK PERSONAL REMAJA
}

\author{
Annisa Nurul Utami, Farida Kurniawati \\ e-mail: ichanurulutami@gmail.com, farida1@ui.ac.id \\ Fakultas Psikologi, Universitas Indonesia
}

Jalan Prof. Dr. Sudjono D. Pusponegoro, Kampus UI Depok

\begin{abstract}
Abstrak: Perkembangan teknologi di era digital ini telah memperluas cakupan media elektronik smartphone sampai kepada kalangan remaja. Smartphone memiliki fungsi utama sebagai alat bantu komunikasi jarak jauh dan pencarian informasi melalui internet secara umum. Di luar itu, bagi remaja yang masih bersekolah ternyata kemunculan smartphone tidak hanya memberikan dampak positif bagi perkembangan kualitas capaian pendidikan mereka, tetapi juga berpotensi memberikan ragam dampak negatif. Dari itu, tinjauan sistematis ini mengumpulkan hasil studi ilmiah kuantitatif dan kualitatif mengenai dampak-dampak negatif adiksi smartphone terhadap aspek-aspek akademik personal remaja. Studi ini menggunakan pencarian dari dua database melalui penjelasan bentuk metasummary kualitatif. Sebanyak 10 studi terpilih berdasarkan kriteria seleksi. Hasil penelusuran studi-studi terpilih menunjukkan bahwa adiksi smartphone pada remaja sekolah menengah pertama dan sekolah menengah atas dapat berisiko menurunkan prestasi akademik, menurunkan keterlibatan akademik, mendorong munculnya perasaan tidak puas pada sekolah, meningkatkan perasaan cemas, dan memunculkan gejala depresi. Masalah perilaku lainnya yang ditemukan melalui studi terpilih dari adiksi smartphone adalah kerentanan remaja pada beban pikiran berlebihan, pengaturan perhatian, agresivitas aksi antisosial, kesulitan membangun identitas diri positif, dan peningkatan potensi aksi merusak diri. Dari semua dampak tersebut, bagian aspek akademik personal remaja yang paling banyak ditemukan yaitu memburuknya prestasi akademik. Perhatian pada dampak negatif adiksi smartphone terhadap aspek akademik personal remaja dapat memberikan informasi bagi orangtua, guru, dan para profesional dalam menyusun antisipasi kerugian akademik bagi remaja, seperti dalam menyusun program sosialisasi untuk mengedukasikan penggunaan smartphone secara bijak.
\end{abstract}

Kata Kunci: adiksi smartphone, aspek akademik personal, prestasi akademik, remaja

\section{THE NEGATIVE IMPACTS OF SMARTPHONE ADDICTION ON ADOLESCENT'S PERSONAL ACADEMIC ASPECTS}

Abstract: Technology development in today's digital era expands the scope of electronic media, such as smartphone, to be more easily accessed by adolescents. A smartphone has indeed the main functions generally as a means of communication in distance barriers, and a means of information gathering through the Internet. In spite of this, the prevalence of smartphones among adolescents affects not merely in beneficial way to their academic experiences quality, but also could potentially give negative impacts. Therefore, this systemathic review collects the findings of both relevant quantitive and qualitative studies regarding the negative impacts of smartphone addiction on adolescent's personal academic aspects. Selected studies were identified from two databases to be presented in qualitative metasummary. We selected 10 studies based on the selection criteria. From the assessment, results found that smartphone addiction among senior and junior high school students could raise some risks as follows: lower academic achievements, decreased academic engagement, increased academic institution disaffection, higher tendency of anxiety, and deeper depression symptoms. Other problematic behaviors that were observed in one of 
selected studies were: thought problems, attention problems, antisocial-action-related aggressiveness, difficulties in building positive self-identity, and greater problems relating to self-destruction. The most frequently discovered personal academic aspect as a negative impact mentioned by participants was the decrease of academic achievement. This consideration about negative impacts of smartphone addiction on personal academic aspects offers information for parents, teachers, and the professionals to construct the anticipations of academic-related disadvantages for adolescents (e.g., an educative socialization program about utilizing smartphone wisely).

Keywords: academic achievement, adolescence, personal academic aspects, smartphone addiction

\section{PENDAHULUAN}

Perkembangan teknologi saat ini telah mencapai kemajuan yang cukup berarti bagi kemajuan kualitas hidup manusia. Masyarakat semakin merasakan kemudahan untuk berkomunikasi dan mencari informasi, sehingga tidak terhalang oleh jarak dan waktu. Data survei UNICEF, Kementerian Komunikasi dan Informasi (Kominfo), dan Berkman Center for Internet and Society menunjukkan bahwa $84 \%$ dari total penduduk di Indonesia memiliki telepon seluler (Broto, 2014). McDonald (2018) mengungkap sekitar 4 miliar orang di dunia kini memiliki akses internet, dengan peningkatan jumlah pengguna rata-rata berkisar 4 miliar orang, jumlah pengguna media sosial 3 miliar orang, dan jumlah pengguna ponsel pintar 5 miliar orang. Angka tersebut menandakan Indonesia pada peringkat kelima perihal jumlah pengguna internet dunia setelah Cina, India, Amerika Serikat, dan Brasil (Internet World Stats, 2018). Terlebih, Global Web Index 2017 dalam McDonald (2018) memosisikan Indonesia sebagai negara keempat paling banyak menghabiskan waktu untuk akses internet

BBerkaitan dengan hal di atas, fenomena adiksi mengikuti semakin maraknya penggunaan smartphone dan internet. Konsep adiksi berasal dari kosa kata Bahasa Latin yang berarti 'enslaved by' atau 'diperbudak oleh'. Adiksi terdefinisi sebagai pengaruh bagian otak yang bertahan lama dan kuat dengan tiga karakteristik khas, yaitu: kemauan kuat dalam menggunakan suatu objek, kehilangan kontrol penggunaannya, dan selalu terlibat dengan objek tersebut tanpa mengkhawatirkan efek bahayanya (Harvard Health Publishing, 2011). Adiksi ini dapat berbentuk adiksi obat-obatan terlarang dan berupa adiksi smartphone sebagai salah satu alat teknologi populer penyedia internet saat ini (Sinkkonen, Puhakka, \& Meriläinen, 2014). Secara umum, adiksi terjadi ketika individu selalu merasa terdorong pada aksi menggunakan suatu benda tertentu (Alavi, Ferdosi, Jannatifard, Eslami, Alaghemandan, \& Setare, 2012). Hal itu tidak menutup kemungkinan berkembang pada penggunaan smartphone yang mempermudah akses internet untuk dibawa kemana pun. Samaha dan Hawi (2016) memperjelas bahwa melalui smartphone, konten internet mencakup menelepon, mengirim surat elektronik, menonton dan berbagi konten foto atau video, bermain games, memutar musik, menentukan tempat pertemuan, menjelajahi internet, pencaran suara, mengecek cuaca, dan melakukan pesan singkat dalam chatroom media sosial. Daya tarik smartphone karenanya kini semakin meningkat sampai ke kalangan remaja yang rentan terpengaruh (Nakaya, 2014). Hasil riset tersebut didukung Ho, Lwin, dan Lee (2017) yang mendata berdasarkan survei di Singapura bahwa remaja adalah populasi yang paling banyak terdeteksi menggunakan media sosial di smartphone secara berlebihan, atau bahkan sampai berujung pada adiksi.

Perkembangan manusia di masa remaja sendiri adalah periode yang sangat sensitif dalam memunculkan keinginan tinggi untuk bermain ragam permainan dan menghabiskan banyak waktu pada media sosial (Ayar, Bektas, Bektas, Akdeniz Kudubes, Selekoglu Ok, Sal Altan, \& Celik, 2017). Lee dan Lee (2017) menyebutkan remaja yang biasanya sangat rentan terpengaruh adiksi smartphone adalah mereka berprestasi rendah di bidang akademik, hubungan sosial dengan keluarga yang tidak baik, dan tingginya ketidakpuasan pada kehidupan sekolah. Manifestasi penggunaan smartphone ini di antaranya adalah demi mendapatkan pengakuan teman sebaya dan akses informasi hiburan. Studi lain menemukan penggunaan internet melalui smartphone rata-rata digunakan guna mencari informasi, menemukan hiburan, dan bermain games (Sinkkonen, Puhakka, \& Meriläinen, 2014). Terkait itu, Agusta (2016) mendata secara deskriptif faktor-faktor penyebab remaja kecanduan smartphone, yakni: keinginan pencarian sensasi tinggi, self-esteem rendah, situasi psikologis, pemasaran produk smartphone, atribut smartphone yang menarik, dan manfaat perluasan interaksi sosial. Kemampuan mengontrol diri dan perasaan terisolasi juga menentukan sejauh mana remaja teradiksi smartphone (Lim \& You, 2018; Yun, Kim, \& Kwon, 2018). Bila kontrol dirinya rendah dan memiliki kecenderungan cepat merasa bosan, smartphone yang 
bisa memberikan respon cepat menjadi objek yang sangat menarik bagi mereka. Hal ini menunjukkan bahwa penelitian terhadap aktivitas penggunaan smartphone pada remaja menjadi penting untuk dilakukan, terutama bila penggunaannya sampai melebihi batas normal.

Keterbukaan akses teknologi seperti melalui smartphone saat ini tidak selalu memberikan dampak positif. Beberapa masalah perilaku dan psikologis, baik oleh orang dewasa, remaja, maupun anak-anak, menjadi salah satu buktinya. Dari dampak positif, Yi, You, dan Bae (2016) menemukan penggunaan smartphone secara intensif pada pelajar bisa meningkatkan persepsi remaja yang lebih positif pada kinerja akademik. Apalagi, hal itu didukung ketersediaan ragam smartphone yang semakin praktisnya fitur-fiturnya, semakin tinggi kecepatan akses informasi, dan semakin terjangkaunya jenis smartphone (Juraman, 2014). Pelajar dapat memperluas wawasan tentang materi akademik dengan memanfaatkan fungsi smartphone, sehingga tidak hanya bergantung pada buku dan materi dari guru di sekolah (Dewanti, Widada, \& Triyono, 2016; Muflih, Hamzah, \& Puniawan, 2017). Selain itu, smartphone dapat pula mendorong kerjasama antarsiswa dari memudahkan komunikasi dan menunjang perkembangan kreativitas (Aljomaa, Qudah, Albursan, Bakhiet, \& Abduljabbar, 2016).

Walaupun demikian, dari sisi negatif ketergantungan berlebihan pada fungsi smartphone dapat mengakibatkan perasaan stres hingga gejala adiksi (Jun, 2015; Lee, Chang, \& Cheng, 2014; van Deursen, Bolle, Hegner, \& Kommers, 2015). Fenomena di Indonesia sendiri menunjukkan penggunaan smartphone pada remaja yang melebihi frekuensi 3 jam sehari yang umumnya seputar akses media sosial, bermain games yang justru dilakukan di waktuwaktu istirahat (Muflih, Hamzah, \& Puniawan, 2017). Penggunaan smartphone sendiri bila lebih dari 4 jam sehari akan memperparah kecenderungan adiksi (Aljomaa et al., 2016). Dari itu, kualitas istirahat remaja pun berkurang, bahkan dapat mengurangi kualitas interaksi dengan orangtuanya (Muflih, Hamzah, \& Puniawan, 2017). Terlebih, Kibona dan Mgaya (2015) memperlihatkan tingginya pemakaian smartphone dapat mengganggu proses pembelajaran sebagaimana penggunaannya bisa mencapai 5 sampai 7 jam per hari untuk sosial media. Durasi ini jauh melebihi pemanfaatan smartphone remaja pada konteks akademik. Contohnya penggunaan aplikasi Facebook, sebagai media sosial terpopuler, bila terjadi secara berlebihan dapat memprediksi semakin rendahnya prestasi akademik (Junco, 2012).

Berdasarkan itu, studi kajian ilmiah kali ini berfokus pada adiksi smartphone di kalangan remaja, terutama dalam membahas dampak-dampak negatif dari adiksi yang berpotensi mengganggu pencapaian aspek-aspek akademik personal remaja. Aspekaspek akademik personal pelajar ini disimpulkan sebagai kesatuan ragam aspek personal yang dapat berperan dalam menentukan kinerja akademik, yakni: keterlibatan akademik, kecemasan, kepuasan pada sekolah, penurunan perhatian, serta depresi (Adeyemi \& Adeyemi, 2014; Frazier, 2016; McLeod, Uemura, \& Rohrman, 2012; Steinmayr, Crede, McElvany, \& Wirthwein, 2016). Selain itu, penelitian dilakukan atas dasar keterbatasan pengumpulan hasil studi empiris berbentuk tinjauan sistematis pada fenomena adiksi smartphone. Terlebih, topik mengenai faktor-faktor psikologis personal yang penting bagi kesuksesan akademik remaja. Hawi dan Samaha (2016) mengungkap saat risiko kecanduan penggunaan smartphone semakin besar, bahkan pada kalangan mahasiswa, akan berpotensi menimbulkan penurunan hasil prestasi akademik. Sementara itu, studi literasi yang mengkaji dampak negatif adiksi smartphone di kalangan pelajar remaja yang mengungkap efeknya terhadap prestasi akademik belum banyak dilakukan. Berdasarkan hal tersebut, penelitian ini penting dilakukan mengingat pelajar remaja adalah kelompok pengguna smartphone yang sebenarnya lebih berisiko dalam mendapatkan pengaruh media, baik negatif maupun positif. Berkenaan itu, Schunk, Pintrich, dan Meece (2012) menyebutkan bahwa faktor penentu capaian akademik dari sisi psikologis pelajar dapat berupa motivasi belajar, keterlibatan akademik, dan regulasi diri. Walaupun lingkungan fisik sekolah dapat pula berpengaruh, faktor tersebut tidak cukup menjamin peningkatan prestasi akademik jika tanpa keterlibatan akademik siswa yang cukup (Dotterer \& Lowe, 2011).

Dengan demikian, kajian literasi ilmiah kali ini bertujuan mengumpulkan temuan studi ilmiah kuantitatif dan kualitatif mengenai dampak negatif adiksi smartphone terhadap aspek-aspek akademik personal remaja sekolah menengah. Adapun gambaran umum studi literatur untuk menjawab: 'Apa saja dampak negatif dari adiksi penggunaan smartphone pada aspek-aspek akademik personal remaja?'

\section{METODE PENELITIAN}

\section{Sumber Data dan Strategi Pencarian}

Pembatasan istilah pencarian studi literatur 
pada kategori aspek akademik personal dipilih melalui konsep motivasi belajar atau akademik, keterlibatan akademik, dan regulasi diri. Ketiganya merupakan bagian dari faktor-faktor penentu capaian akademik remaja berdasarkan Schunk, Pintrich, dan Meece (2012) yang diduga memiliki keterkaitan dengan adiksi smartphone. Strategi pencarian adalah melalui alat pencarian riset Integrated Search from ProQuest Summon Serials pada Perpustakaan Universitas Indonesia akses jarak jauh. Database seleksi literatur pada penelitian ini yaitu Sage Journals dan ScienceDirect. Penelusuran dilakukan dari 16 Oktober 2018 sampai 24 Oktober 2018. Proses seleksi studi yang dieliminasi dan studi yang diikutsertakan pada analisis lanjutan terdiri atas screening, pembacaan, dan identifikasi judul atau abstrak studi-studi dari kedua database.

Kata kunci pencarian pada database Sage Journals yakni: (a) ('smartphone usage' AND 'addiction' AND 'adolescence' AND 'academic achievement'); dan (b) ('smartphone' AND 'mobile phone' AND 'usage' AND 'addiction' AND 'academic motivation'). Dari proses pertama (a), peneliti menemukan 77 studi ilmiah sebelum seleksi lanjutan yang berkaitan dengan kata kunci. Dari proses kedua (b), peneliti hanya menemukan 44 studi terkait kata kunci. Pencarian studi pada database menggunakan batasan periode publikasi dan riset antara 2010 sampai 2018. Peneliti juga menyaring data pencarian hanya untuk artikel penelitian ilmiah yang sudah melalui proses peerreview.

Di samping itu, pencarian melalui database ScienceDirect adalah dengan menggunakan kata kunci sebagai berikut: (a) ('smartphone addiction/ overuse' AND 'adolescent' AND 'self-regulation'); (b) ('smartphone addiction/ overuse' AND 'adolescent' AND 'academic motivation'); dan (c) ('smartphone addiction/ overuse' AND 'adolescent' AND 'academic performance'). Perbedaan kata kunci ini dilakukan guna melihat variasi studi terkait aspek psikologis yang dapat menentukan prestasi akademik remaja dan menghindari hasil penelusuran yang sama dengan hasil di database pertama. Pencarian dengan self-regulation menemukan 69 studi, pada academic motivation 83 studi, dan pada academic performance berjumlah 32 studi. Dari total tersebut, studi yang terpilih untuk ditelaah lebih lanjut hanya berjumlah 7 studi, 4 dari academic motivation, 1 dari self-regulation, dan 2 dari academic performance.

\section{Kriteria Pemilihan dan Eliminasi Studi}

Berdasarkan pencarian database pertama, jumlah studi terseleksi yakni 3 penelitian yang merupakan kombinasi dari studi kualitatif dan kuantitatif. Pada database kedua, studi terpilih hanya berjumlah 7 studi. Seleksi ini berdasarkan pada eliminasi studi-studi yang berada di luar konteks pencarian, seperti: kriteria partisipan yang tidak sesuai dengan konteks remaja (mahasiswa dan pekerja), studi mengenai faktor yang melatarbelakangi adiksi smartphone, studi literatur mengenai metode penelitian, dan studi tentang variabel lain yang tidak berhubungan (relasi ibu dan ayah pada remaja, pengasuhan anak, data personal, intervensi pencegahan adiksi, dan lain-lain).

Cukup selaras dengan kategori eliminasi database sebelumnya, eliminasi database kedua ditujukan pada studi-studi ilmiah dengan subjek penelitian berbeda (mahasiswa, orangtua, remaja yang sudah teridentifikasi kecemasan khusus atau gejala klinis tertentu), studi terkait faktor-faktor adiksi smartphone, masalah adiksi lain (obat terlarang dan game online), studi efektivitas program intervensi adiksi smartphone, studi pengembangan alat ukur adiksi smartphone, studi efek sosiokultural, serta studi yang dipublikasikan dengan bahasa lain (non-English).

\section{Pemilihan Studi}

Dalam pencarian studi, peneliti menemukan beberapa studi yang mempunyai judul sama walaupun melalui kata kunci berbeda. Untuk mencegah duplikasi, studi berjudul sama diputuskan untuk diakumulasi dengan proses pencarian pertama kali, seperti studi Alt dan Boniel-Nissim (2018) yang ditemukan beberapa kali pada database kedua. Lalu, studi tersebut diputuskan hanya terhitung pada jumlah studi kata kunci pertama. Proses pemilihan data terdiri atas: (1) identifikasi judul, nama peneliti, serta abstrak; (2) screening artikel penelitian, terutama pada bagian tujuan penelitian, metode, dan hasil; (3) penilaian apakah studi terseleksi pada analisis atau tereliminasi; dan (4) pemberian keputusan studi terseleksi atau tereliminasi. Dari total 121 studi dari pencarian database pertama, 11 studi dipertimbangkan sampai memasuki tahap penilaian dan hanya 3 studi yang diputuskan terseleksi. Pada database kedua, total studi yang dipertimbangkan adalah 13 studi dan terseleksi hanya 7 studi. Berdasarkan itu, total studi yang dikaji lebih lanjut pada penelitian adalah 10 studi. Gambar 1 dan 2 pada bagian "Hasil dan Pembahasan" memperlihatkan alur diagram tahap pemilihan studi pada dua database.

\section{Sintesis Data}

Proses tinjauan sistematis penelitian ini mengacu pada bentuk qualitative metasummary dari Sandelowski, 
Barroso, dan Voils (2007) yang menyatukan analisis mendalam pada studi ilmiah kuantitatif dan kualitatif. Studi kuantitatif memperlihatkan hubungan dua atau lebih variabel dengan analisis melalui standarisasi statistik sains sosial, sedangkan studi kualitatif memberikan temuan berdasarkan analisis mendalam bentuk teoritis dan pengambilan data wawancara terbuka serta focus group discussion. Mengacu pada studi qualitative metasummary sejenis, penelitian ini mengaplikasikan tahapan analisis dari Tromp, Zwaan, dan van de Vathorst (2016). Tahap pertama yaitu ekstraksi hasil studi terkait konsep utama, dimana pada studi kali ini adalah adiksi smartphone. Tahap kedua yaitu pembuatan daftar hasil dari tiap studi terseleksi agar sesuai dengan kategori faktor. Pada studi ini, daftar hasil bukan terkait faktor, melainkan efek adiksi smartphone yang berhubungan dengan aspek akademik personal. Tahap ketiga, pengelompokan efek adiksi sesuai kategori dan penyajiannya dalam bentuk terintegrasi. Prosedur yang dilakukan adalah melalui pembacaan literasi terseleksi secara seksama, teliti, dan independen. Peneliti menggarisbawahi unsur-unsur penting tiap studi, terutama yang berkaitan dengan adiksi smartphone, motivasi belajar, dan regulasi diri. Dari variasi istilah yang ditemukan, peneliti kemudian membuat kategori berdasarkan temuan sejenis dalam satu konsep. Contohnya motivasi akademik dengan kategori motivasi belajar, atau adiksi jaringan sosial internet dengan kategori adiksi smartphone. Adapun keseluruhan kategori berupa: prestasi akademik, keterlibatan akademik, ketidakpuasan dengan sekolah, kecemasan, depresi, dan masalah perilaku lainnya dari penilaian laporan diri remaja.

\section{HASIL DAN PEMBAHASAN}

\section{Hasil}

Berdasarkan pencarian literatur, kedua database yang digunakan dengan keyword tidak memperlihatkan hubungan atau pengaruh langsung terhadap adiksi smartphone pada self-regulation, academic motivation, dan academic performance remaja.Hasil pencarian memberikan studi smartphone yang berkaitan dengan aspek-aspek akademik personal remaja lainnya, yakni berupa prestasi akademik, keterlibatan akademik, ketidakpuasan dengan sekolah, kecemasan, depresi, dan masalah perilaku lainnya dari penilaian laporan diri remaja.

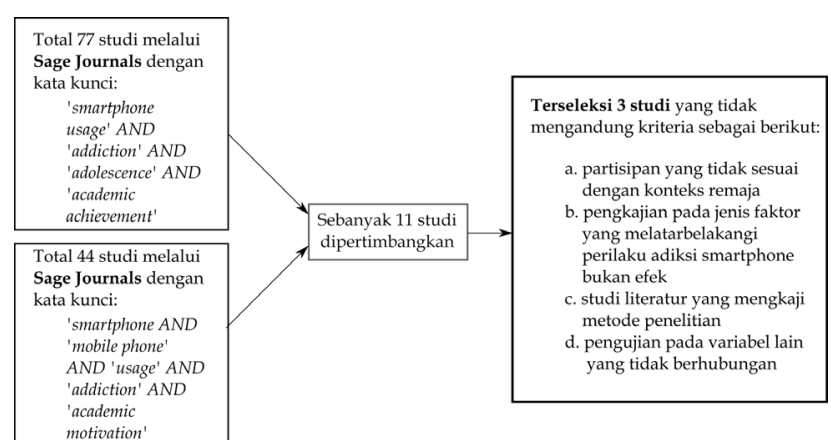

Hasil pencarian Hasil Seleksi Hasil Penilaian (identifikasi) (screening) (eliminasi)

Gambar 1. Alur diagram identifikasi, seleksi. penilaian, dan eliminasi database satu

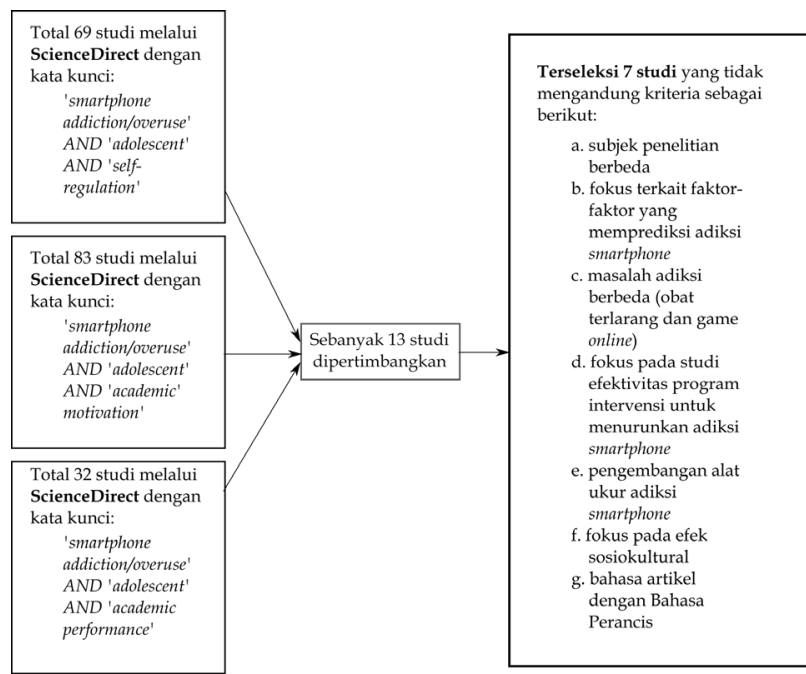

Hasil Pencarian Hasil Seleksi Hasil Penilaian (identifikasi) (screening) (eliminasi)

Gambar 2. Alur diagram identifikasi, seleksi, penilaian, dan eliminasi database dua

Pemilihan Studi. Studi yang terpilih berjumlah 10 yang secara dominan adalah riset kuantitatif. Kriteria pemilihan dari proses penilaian mengalami beberapa perubahan berdasarkan dukungan literasi lain, seperti tidak hanya studi dengan judul yang spesifik mengarah pada adiksi smartphone saja disintesis, namun beberapa istilah dipertimbangkan. Istilah yang paling sering ditemukan adalah adiksi internet, adiksi situs jaringan sosial (Social Networking Sites/SNS), penggunaan teknologi informasi dan komunikasi (Informastion and Communications Technology/ICT) pada non-akademis, ketergantungan ponsel seluler, dan penggunaan bermasalah pada internet. Pertimbangan masuknya judul adiksi internet karena studi terkait memasukkan smartphone sebagai bentuk kecil dari komputer (desktop), sebagaimana smartphone adalah alat teknologi yang 
memadukan kegunaan ponsel seluler dan kegunaan internet, sehingga umumnya memiliki kesamaan gejala kecanduan dan efek negatifnya (Alt \& BonielNissim, 2018; Cha \& Seo, 2018; David, Kim, Brickman, Ran, \& Curtis, 2015; Uzun \& Kilis, 2019). Selain itu, studi membuktikan hubungan signifikan positif adiksi internet dengan adiksi smartphone yang bermakna semakin tingginya adiksi internet berhubungan pula dengan meningkatnya adiksi smartphone yang terjadi di remaja sekolah (Ayar et al., 2017; Jun, 2015). Di samping itu, ICT yang lebih merujuk pada alatnya juga banyak diasosiasikan dengan ponsel pintar yang saat ini banyak digunakan remaja untuk berkomunikasi jarak jauh dan selalu terhubung dengan manfaat internet (Granholm, 2016; Salomon \& Kolikant, 2016). Adapun pada SNS, istilah tersebut merujuk pada fitur dalam ICT yang terhubung dengan internet yang menyediakan layanan komunikasi media sosial yang kini marak digunakan banyak orang di seluruh dunia dan salah satu latar belakang penggunaan berlebihan pada smartphone (Wang et al., 2018). Terlepas dari itu, melalui identifikasi, screening, penilaian, sampai pemberian keputusan, data pada studi yang terseleksi terangkum pada Tabel 1 dengan data 10 studi terseleksi sebagai berikut.

Tabel 1

Tipe Penelitian, Metode Penarikan Data, dan Karakteristik Partisipan Studi-Studi Terseleksi

\begin{tabular}{|c|c|c|c|c|c|c|}
\hline \multirow[b]{2}{*}{ No } & \multirow{2}{*}{ Studi } & \multirow{2}{*}{$\begin{array}{c}\text { Tipe } \\
\text { Penelitian }\end{array}$} & \multirow{2}{*}{ Penarikan Data } & \multicolumn{3}{|c|}{ Karakteristik Partisipan } \\
\hline & & & & Status Pendidikan & Usia & Total (n) \\
\hline 1 & $\begin{array}{l}\text { Cha dan Seo } \\
(2018)\end{array}$ & Kuantitatif & $\begin{array}{l}\text { Pengisian kuesioner tertulis terstandarisasi oleh } \\
\text { partisipan }\end{array}$ & SMP & $13-15$ & 1.824 \\
\hline 2 & $\begin{array}{l}\text { Lee, Sung, } \\
\text { Song, Lee, Lee, } \\
\text { Cho, Park, dan } \\
\text { Shin (2018) }\end{array}$ & Kuantitatif & $\begin{array}{l}\text { Pengisian kuesioner tertulis terstandarisasi oleh } \\
\text { partisipan }\end{array}$ & SMP & 14,8 & 490 \\
\hline 3 & $\begin{array}{l}\text { Alt dan } \\
\text { Boniel-Nissim } \\
(2018)\end{array}$ & Kuantitatif & $\begin{array}{l}\text { Pengisian kuesioner tertulis terstandarisasi oleh } \\
\text { partisipan }\end{array}$ & $\begin{array}{l}\text { SMP }(45,6 \%) \text { dan } \\
\text { SMA }(54,5 \%)\end{array}$ & $\begin{array}{c}13-15 ; 15 \\
-18\end{array}$ & 270 \\
\hline 4 & $\begin{array}{l}\text { Yun, Kim, dan } \\
\text { Kwon (2015) }\end{array}$ & Kuantitatif & $\begin{array}{l}\text { Pengisian kuesioner tertulis terstandarisasi dan } \\
\text { pertanyaan terbuka }\end{array}$ & SMP & 13,9 & 1.629 \\
\hline 5 & $\begin{array}{l}\text { Zhang, Qin, } \\
\text { dan Ren (2018) }\end{array}$ & Kuantitatif & $\begin{array}{l}\text { Pengisian kuesioner tertulis terstandarisasi oleh } \\
\text { partisipan dan data sekunder berupa nilai mata } \\
\text { pelajaran di sekolah }\end{array}$ & SMP & 12,9 & 2.407 \\
\hline 6 & $\begin{array}{l}\text { Oberst, } \\
\text { Wegmann, } \\
\text { Stodt, Brand, } \\
\text { dan Chamarro } \\
\text { (2017) }\end{array}$ & Kuantitatif & $\begin{array}{l}\text { Pengisian kuesioner tertulis terstandarisasi oleh } \\
\text { partisipan secara online yang terhubung dengan } \\
\text { Facebook sebagai salah satu situs jaringan sosial } \\
\text { (SNS) }\end{array}$ & SMA & $16-18$ & 1.468 \\
\hline 7 & $\begin{array}{l}\text { Sinkkonen, } \\
\text { Puhakka, dan } \\
\text { Meriläinen } \\
\text { (2014) }\end{array}$ & Kualitatif & $\begin{array}{l}\text { Partisipan menjawab pertanyaan terbuka yang } \\
\text { mana jawaban akan melalui kategorisasi }\end{array}$ & $\begin{array}{l}\text { SMP }(49 \%) \text { dan } \\
\text { SMA }(51 \%)\end{array}$ & $15-19$ & 475 \\
\hline 8 & $\begin{array}{l}\text { Seo, Park, } \\
\text { Kim, dan Park } \\
(2016)\end{array}$ & Kuantitatif & $\begin{array}{l}\text { Pengisian kuesioner tertulis terstandarisasi oleh } \\
\text { partisipan dan wawancara untuk penentuan } \\
\text { waktu survei }\end{array}$ & SMP dan SMA & $15-18$ & 2.159 \\
\hline 9 & $\begin{array}{l}\text { Salomon } \\
\text { dan Kolikant } \\
(2016)\end{array}$ & Kualitatif & $\begin{array}{l}\text { Pengisian tiga data survei (demografi, latar } \\
\text { belakang; persepsi hubungan penggunaan ICT } \\
\text { non-akademis; dan dampak ada menurunnya } \\
\text { penggunaan ICT non-akademis pada prestasi } \\
\text { akademik), serta diskusi fokus grup }\end{array}$ & SMA & $13-17$ & 533 \\
\hline 10 & $\begin{array}{l}\text { Liu, } \\
\text { Kirschner, dan } \\
\text { Karpinskic } \\
\text { (2017) }\end{array}$ & Kualitatif & $\begin{array}{l}\text { Pengumpulan hasil studi-studi kuantitatif } \\
\text { untuk meta-analisis hubungan adiksi SNS dan } \\
\text { performa akademik }\end{array}$ & $\begin{array}{l}\text { SMP dan SMA; } \\
\text { serta maha } \\
\text { siswa }\end{array}$ & $15-23$ & $88.874 ; 12.973$ \\
\hline & & & Total partisipan remaja dari 10 studi & & & 100.129 orang \\
\hline
\end{tabular}


Metasummary Kualitatif dari Efek Negatif Adiksi Smartphone. Berdasarkan sintesis yang dilakukan pada 10 studi ilmiah kuantitatif dan kualitatif, jumlah subjek penelitian yang berada dalam karakteristik remaja sekolah menengah adalah sebagai berikut per studi ilmiah (Tabel 1). Total keseluruhan remaja dalam studi literatur kali ini menjadi 100.129 remaja yang berasal dari populasi siswa sekolah menengah pertama dan sekolah menengah atas. Nilai total tersebut sudah mencakup eliminasi jumlah sampel mahasiswa yang diperhitungkan pada penelitian Liu, Kirschner, dan Karpinskic (2017) sebanyak 12.973 orang. Data tersebut berdasarkan pada rentang usia remaja yang paling rentan untuk menghadapi adiksi smartphone yakni antara 14 sampai dengan 18 tahun (Ayar et al., 2017). Adapun berdasarkan pengkajian lebih lanjut berkenaan dengan dampak negatif dari adiksi smartphone yang dapat berisiko pada keberhasilan prestasi akademis remaja meliputi timbulnya permasalahan kesehatan psikologis, kecemasan yang meningkat (Cha \& Seo, 2018; Lee, Sung, Song, Lee, Lee, Cho, Park, \& Shin, 2018), penurunan keterlibatan akademik (Sinkkonen, Puhakka, \& Meriläinen, 2014; Zhang, Qin, \& Ren, 2018), penurunan prestasi akademik (Alt \& Boniel-Nissim, 2018; Liu, Krischner, \& Karpinski, 2017; Oberst, Wegmann, Stodt, Brand, \& Chamarro, 2017; Seo, Park, Park, \& Kim, 2016; Salomon \& Kolikant, 2016; Yun, Kim, \& Kwon, 2018; Zhang, Qin, \& Ren, 2018), peningkatan sikap ketidakpuasan pada institusi akademik (Zhang, Qin, \& Ren, 2018), penurunan kesempatan akademik (Oberst et al., 2017); efisiensi waktu belajar yang menurun, penarikan sosial, penurunan konsentrasi pada tugas akademik, penurunan konsentrasi belajar di sekolah (Seo et al., 2016; Sinkkonen, Puhakka, \& Meriläinen, 2014), serta peningkatan risiko depresi (Alt \& BonielNissim, 2018; Seo et al., 2016). Terdapat beberapa efek negatif dari luaran adiksi smartphone pada beberapa studi secara terpisah, yakni peningkatan risiko depresi, efisiensi waktu belajar yang menurun, penarikan sosial, penurunan konsentrasi pada tugas akademik, dan peningkatan sikap ketidakpuasan pada institusi akademik. Untuk itu, bagian diskusi akan membahasnya lebih lanjut.

\section{Pembahasan}

Prestasi Akademik. Mengacu pada sintesis hasil penelitian dari 10 studi, efek negatif pada remaja sekolah menengah yang paling sering ditemukan dari munculnya fenomena penggunaan smartphone yang berlebihan adalah penurunan prestasi akademik. Hasil tersebut didapatkan baik dari studi yang berjenis kuantitatif (Alt \& Boniel-Nissim, 2018; Oberst et al., 2017; Seo et al., 2016; Yun, Kim, \& Kwon, 2018; Zhang, Qin, \& Ren, 2018) maupun dari kajian ilmiah kualitatif (Liu, Krischner, \& Karpinski, 2017; Salomon \& Kolikant, 2016). Hasil ini menunjukkan tidak hanya berupa ketidaksadaran dari remaja pengguna smartphone saja efek negatif ini berlaku, akan tetapi sebenarnya beberapa remaja telah mengakui adanya perubahan pada prestasi mereka apabila frekuensi menggunakan smartphone semakin tinggi. Kesadaran ini didasarkan pada pernyataan evaluasi subjektif remaja (Alt \& Boniel-Nissim, 2018; Liu, Krischner, \& Karpinski, 2017; Salomon \& Kolikant, 2016). Sinkkonen, Puhakka, dan Meriläinen (2014) menjelaskan dengan adiksi smartphone daya konsentrasi belajar remaja semakin berkurang. Efek negatif adiksi smartphone pada pencapaian prestasi akademik ini pun berhubungan dengan mekanisme internal yang terjadi pada diri remaja seperti penurunan keterlibatan akademik (Zhang, Qin, \& Ren, 2018). Untuk itu, beberapa efek lain terkait aspek akademik personal remaja secara rinci yang berpotensi mendorong terjadinya penurunan prestasi juga diperhatikan pada studi ini. Oberst et al. (2017) menemukan bagian mekanisme internal yang dapat menjelaskan perubahan prestasi tersebut di antaranya yakni mekanisme terkait emosi, seperti kecemasan dan depresi.

Terlepas dari itu, Seo et al. (2016) menunjukkan prestasi akademik yang menurun dari aktivitas smartphone dapat berada pada relativitas materi pembelajarannya. Pada studinya, pengaruh signifikan hanya ditemukan secara langsung dari adiksi smartphone menuju prestasi remaja di pelajaran matematika, namun tidak demikian pada pelajaran bahasa. Perbedaan pengaruh pada prestasi akademik ini juga dapat berbeda sesuai kualitas akademik remaja sehari-harinya. Kelompok remaja dengan prestasi lebih tinggi sebagian besar berpendapat bahwa penggunaan smartphone pada aktivitas non akademis tidak akan mengganggu mereka karena mereka tidak memerlukan waktu lama dalam mengerjakan tugas sekolah (Salomon \& Kolikant, 2016). Selain itu, remaja kategori ini mengaku tidak terlalu intensif memanfaatkan penggunaan smartphone dengan tujuan yang non-akademis. Lain halnya dengan kelompok remaja prestasi lebih rendah, mereka cenderung menunjukkan ketidakpercayaan bahwa pengurangan aktivitas non-akademis pada penggunaan smartphone dapat membantu meningkatkan nilai. Adapun remaja dengan tingkat prestasi kategori sedang cenderung percaya pengurangan penggunaan ICT tujuan nonakademis dapat membantu mereka dalam berupaya 
meningkatkan nilai di sekolah.

Lain dari itu, mengacu pada studi kualitatif, Liu, Krischner, dan Karpinski (2017) mengungkap bahwa intensitas penggunaan berlebih pada SNS seperti media sosial dengan prestasi akademik lebih konsisten pada pengguna yang berada pada periode remaja sekolah menengah daripada mahasiswa. Semakin tinggi penggunaan SNS pada remaja, maka semakin rendah performa akademik mereka. Hal ini namun mendapat pengecualian, karena selaras dengan Salomon dan Kolikant (2016), penggunaan SNS untuk kepentingan sosial berhubungan negatif dengan performa akademik, sedangkan penggunaan dalam konteks pencarian infomasi dan edukasi berhubungan positif dengan nilai akademik.

Keterlibatan Akademik. Pengaruh negatif pada luaran akademik dapat dijelaskan pula dari halangan tertentu yang dapat terjadi sebelum masa evaluasi pendidikan remaja (prestasi akademik). Dengan meningkatnya intensitas penggunaan smartphone, remaja lebih sering menunjukkan sikap keterlibatan akademik rendah (Seo et al., 2016; Sinkkonen, Puhakka, \& Meriläinen, 2014; Zhang, Qin, \& Ren, 2018) yang menghantarkan remaja pada rendahnya prestasi akademik. Kemunculan sikap ini dapat ditunjukkan dari bentuk perilaku remaja saat upaya mereka selalu kurang dalam mengerjakan tugas-tugas akademik dan belajar pada persiapan ujian, serta gejala penarikan sosial seperti sering membolos. Remaja lebih menghindari kegiatan akademik saat mulai lebih tertarik pada aktivitas di alat ponselnya (Oberst et al., 2017). Remaja bisa menjadi sering menunda-nunda pengerjaan tugas-tugas mereka dalam tanggung jawabnya sebagai seorang pelajar, serta dapat pula mengalokasikan waktu belajarnya pada hal lain yang tidak produktif (Salomon \& Kolikant, 2016). Contohnya terlalu intensif berkomunikasi dengan teman-teman sebaya, mencari hiburan secara terusmenerus, serta ketagihan mendapatkan penghargaan dari bermain games di ponsel seluler.

Dengan melemahnya prestasi akademik remaja, pada akhirnya tidak sedikit remaja yang merasa menyesal dengan waktu yang mereka habiskan untuk bermain internet dibandingkan untuk mengerjakan tugas sekolah (jumlah responden pada jawaban tersebut adalah 292 remaja) (Sinkkonen, Puhakka, \& Meriläinen, 2014). Daya tarik smartphone yang menyajikan fitur-fitur menarik berakibat pada kurang cakapnya remaja menjaga efisiensi waktu belajarnya, padahal pembatasan waktu penggunaan smartphone diperlukan guna mencapai realisasi tujuan-tujuan belajar (Cutino \& Nees, 2016; Nakaya, 2017). Indikasi lainnya yang menunjukkan keterlibatan akademik yakni remaja cenderung menghabiskan waktu lebih lama untuk bersosialisasi dengan teman-teman sebayanya daripada mempersiapkan ujian sekolah (Sinkkonen, Puhakka, \& Meriläinen, 2014).

Di luar itu, Alt dan Boneil-Nissim (2018) mengungkap bahwa terdapat perbedaan resiko pada keterlibatan akademik ditinjau dari tingkat keparahan adiksi smartphone yang dimiliki remaja. Pada remaja yang berisiko rendah mengalami ketergantungan, mereka lebih cepat menyadari bahwa pengecekan fitur-fitur hiburan di internet melalui smartphone atau dengan komputer memakan banyak waktu sehingga terkesan terbuang sia-sia. permasalahan yang timbul akibat penggunaan berlebihan pada internet. Remaja yang tinggi pada skor dimensi ini menunjukkan kurangnya keaktifan mengerjakan tugas pekerjaan rumah, namun berkebalikan dengan meningkatnya aktivitas terkoneksi dengan internet untuk relasi sosial dengan teman-teman. Tingginya adiksi memperparah keinginan kuat remaja untuk selalu mengecek media sosialnya dan berkomunikasi (Oberst et al., 2017). Dari itu, semakin rendah derajat perhatian akademik remaja yang memperbesar penurunan prestasi di ragam mata pelajaran (Seo et al. (2016)).

Ketidakpuasan Dengan Sekolah. Aspek lain dalam diri remaja sekolah menengah yang dapat memperantarai efek negatif dari adiksi smartphone pada prestasi akademik adalah tingginya derajat ketidakpuasan siswa terhadap sekolah (Zhang, Qin, \& Ren, 2018). Remaja biasanya mengalami kondisi ini karena ia merasa tidak adanya sinkronisasi antara harapan atas perlakuan serta fasilitas yang mampu disediakan sekolah dengan kondisi realita yang didapatkannya. Remaja dengan kepuasan yang rendah juga berpendapat bahwa kebutuhannya tidak bisa sejalan dengan keadaan sekolah. Ketidakpuasan pada sekolah ini pun dimoderasi dengan adanya norma prestasi kelas. Hal tersebut menunjukkan bahwa, tingginya adiksi yang disebabkan oleh ketidakpuasan pada sekolah yang tinggi disertai norma prestasi kelas yang rendah akan menjelaskan pula prestasi remaja yang rendah. Sebaliknya, saat ketidakpuasan tergolong rendah dan norma prestasi kelas tinggi, remaja akan lebih cenderung untuk meningkat prestasi akademiknya (Zhang, Qin, \& Ren, 2018).

Kecemasan. Aspek akademik personal yang satu ini, kecemasan, salah satunya merupakan luaran dari adanya rasa ketidakpuasan yang tinggi pada sekolah (Lee et al., 2018) yang muncul dari penggunaan berlebihan pada smartphone. Remaja dengan keterampilan yang masih berada dalam 
kategori sedang saat berhadapan dengan tugastugas akademik yang terlalu menantang membuat remaja rentan mengalami kecemasan, apalagi saat perhatiannya banyak terganggu oleh aktivitas pengecekan media sosial atau kompetisi games dalam smartphone. Temuan ini pun sejalan dengan Cutino dan Nees (2016) yang menemukan bahwa kecemasan pelajar dapat meningkat drastis saat berada dalam perilaku ketergantungan pemakaian smartphone kategori tinggi. Pengaruh adiksi smartphone ini bahkan lebih tinggi dampak negatifnya pada kecemasan berlebihan pada remaja sekolah karena mereka lebih lebih mudah akses daripada sekedar membuka internet di layar komputer mereka, terlebih smartphone mendukung notifikasi 24 jam untuk setiap pembaharuan pesan elektronik, dan sebagainya (Kim et al., 2018).

Depresi. Berkaitan dengan aspek akademik personal lainnya yang berisiko pada keberhasilan akademik, gejala depresi pada studi Seo et al. (2016) juga ditemukan sebagai luaran dari semakin tingginya ketergantungan smartphone di kalangan remaja sekolah menengah. Pada studi Alt dan Boniel-Nissim (2018) sendiri, depresi merupakan salah satu ciri dari penarikan sosial yang menjadi dimensi pada masalah penggunaan berlebihan internet. Studi tersebut juga mengungkap bahwa pemicu dari munculnya depresi adalah keinginan yang kuat dari dalam diri remaja untuk tetap terkoneksi dengan media sosialnya. Saat upaya pemberhentian akses pun, bila remaja dengan adiksi smartphone tinggi tidak bisa menggunakan smartphonenya seperti biasa, remaja bisa mengalami depresi dari dorongan kuat (craving) yang tidak tersalurkan (Nakaya, 2014). Bila depresi akibat smartphone terjadi, masalah lain dapat timbul, yakni terganggunya relasi sosial remaja dengan orang-orang di sekitarnya seperti guru dan teman-teman (Seo et al., 2016).

Depresi yang dapat menjadi luaran adiksi ini juga berkemungkinan ada keterkaitannya dengan jam tidur yang berkurang sebagai efek negatif dari sisi kesehatan remaja (Lee et al., 2018). Remaja yang teradiksi tinggi dengan smartphone sangat intensif mengecek alat tersebut, sehingga bahkan waktu tidurnya menjadi berkurang. Dari hasi uji mediasi yang dilakukan, Seo et al. (2016) menunjukkan bahwa depresi adalah variabel perantara antara pengaruh adiksi smartphone terhadap capaian akademik di bidang bahasa. Depresi yang semakin serius akan berefek pada semakin menurunnya prestasi di bidang tersebut. Walaupun demikian, pengaruh signifikan yang negatif pada tingkat depresi terjadi dapat pula di bawah kondisi tertentu. Pada remaja sekolah Jepang, intensitas berlebihan pada smartphone baru dapat menjelaskan pengaruh signifikan yang negatif pada tingkat depresi apabila fungsi smartphone lebih terarah pada aktivitas obrolan online dan media sosial (SNS). Sementara itu, bila pemakaian alat tersebut lebih kepada penelusuran informasi, bermain games, dan melihat video, pengaruhnya pada depresi remaja tidak terbukti signifikan (Tamura et al., 2017).

Masalah Perilaku Lainnya. Selain berdasarkan kategorisasi aspek akademik personal yang telah disebutkan, Lee et al. (2018) mengungkap bahwa beberapa masalah perilaku dan emosi lainnya yang berhubungan kuat dengan adanya adiksi smartphone berdasarkan pengakuan subjektif remaja yakni masalah beban pikiran berlebihan, masalah sulitnya mengatur perhatian, masalah timbulnya kecenderungan agresivitas yang menghantarkan pada perilaku antisosial, masalah sulitnya membentuk identitas diri yang positif, serta masalah untuk terlibat perilaku merusak diri.

Dengan demikian, studi metasummary kualitatif ini memberikan gambaran umum efek dari adiksi smartphone yang berdasarkan pada kombinasi hasil penelitian terdahulu baik bentuk kuantitatif maupun kualitatif. Dengan bentuk penelitian kuantitatif, penelitian ini berhasil menunjukkan temuan objektif yang melalui standarisasi baku studi psikologi, sehingga studi-studi tersebut berkontribusi memberikan gambaran umum arah variabel pada aspek akademik personal remaja pada populasi. Sementara itu, studi-studi kualitatif yang terdapat dalam penelitian ini melengkapi data dengan memberikan penjelajahan lebih lanjut yang mendalam berdasarkan persepsi remaja sendiri tentang adiksi smartphone. Oleh sebab itu, masalah lain yang belum diteliti pada bantuk kuantitatif dapat terungkap melalui penjelasan detil dari remaja.

Berdasarkan semua itu, penelitian ini menunjukkan bahwa remaja perlu mendapatkan edukasi serta sosialisasi guna mengantisipasi terjadinya penurunan akademik seperti cara efektif dalam menggunakan smartphone secara bijak. Apabila penggunaan smartphone terlalu sering tertuju pada komunikasi media sosial yang tidak berkaitan dengan akademik atau bahkan game online, remaja akan berpotensi kehilangan kesempatan belajarnya secara optimal, terlebih ragam efek negatif adiksi smartphone yang ada dari segi akademik personal mengindikasikan kontrol diri serta penghargaan diri dapat semakin rendah. Dari itu, keadaan tidak efektif bagi perkembangan sosial remaja ini bila tidak 
segera ditangani akan memperparah keadaan yang tidak hanya merugikan aspek akademik dan prestasi mereka, namun aspek lainnya seperti komunikasi remaja dengan keluarga.

\section{PENUTUP}

Kesimpulan

Penelitian ini secara umum memberikan penjelasan bahwa sebagian besar efek negatif penggunaan smartphone yang berlebihan (adiksi) dapat berpengaruh serius pada aspek-aspek akademik remaja dari segi personalnya. Di antaranya efek negatif yang paling sering ditemukan adalah menurunnya prestasi akademik remaja. Terkait itu, penelitian ini dapat berguna bagi orang-orang dewasa yang berada dalam lingkungan terdekat remaja, seperti orangtua, saudara kandung, profesional bidang psikologi, dan guru. Melalui penelitian ini, setiap pihak-pihak yang berperan penting tersebut diharapkan untuk bisa mengetahui lebih mendalam efek-efek negatif menyangkut kepentingan akademik yang mungkin terjadi pada remaja. Selanjutnya, tindakan preventif dan intervensi pengurangan gejala adiksi smartphone dapat direncanakan dan diaplikasikan.

\section{Batasan Penelitian dan Saran}

Berdasarkan semua itu, penelitian yang bertujuan untuk memberikan gambaran umum secara sistematis tentang efek negatif adiksi penggunaan smartphone pada aspek-aspek akademik personal remaja ini, tidak jauh dari adanya kelemahan. Studi-studi yang melalui sintesis ini belum dapat digeneralisasi untuk gambaran umum lebih luas. Hal itu terkait dominasi topik pengkajian yang lebih banyak dilakukan di daerah Asia Timur, seperti Korea Selatan dan China. Karenanya, hasil belum dapat menjelaskan temuan yang lebih beragam seperti fenomena di Amerika, Eropa, Asia Tengah, dan Afrika. Keterbatasan lain adalah belum ditemukannya studi terkait topik yang sama dalam konteks kajian eksperimental. Dari itu, hasil sintesis belum dapat memberikan penjelasan sebab-akibat. Melalui fokus studi yang hanya merujuk pada remaja sekolah menengah, maka total studi terseleksi menjadi lebih sedikit.

Penelitian selanjutnya dapat mempertimbangkan kajian literatur komprehensif berupa perbandingan populasi mahasiswa, sebagai pelajar yang menerima risiko hampir sama dari penggunaan smartphone. Pencarian lebih lanjut studi-studi kuantitatif juga dapat fokus basis studi eksperimen dan perluasan topik penelitian pada daerah-daerah khusus yang masih berkembang. Seperti di antaranya fokus wilayah Indonesia yang masih terbatas jumlahnya pada riset efek adiksi smartphone remaja sekolah menengah. Hal ini guna saling memperkaya studi literatur komprehensif sehingga lebih bermanfaat pada ragam populasi dunia, terlebih bila efek negatif adiksi smartphone pada aspek-aspek akademis juga ditelaah pada anak sekolah dasar, pelajar mahasiswa, dan pelajar dengan karakteristik disabilitas.

Di luar itu, studi literatur ini telah berhasil menyajikan gambaran umum komprehensif yang telah memadukan sintesis dari riset kuantitatif dan kualitatif. Dengan demikian, penjelasan mengenai dampak negatif yang diturunkan dari penggunaan smartphone di kalangan remaja sekolah memiliki dua sisi. Penelitian dapat menjelaskan sekumpulan penemuan objektif berbasis analisis statistika deskriptif atau inferensial, alat ukur terstandarisasi, jumlah sampel yang lebih tinggi. Selain itu, penelitian ini memberikan penjelasan mendalam terkait topik sama dari penemuan basis analisis teori, wawancara individual, dan data survei. Di samping itu, penelitian ini dapat menjadi landasan urgensi penelitian selanjutnya terkait pendidikan, terutama di Indonesia yang masih memiliki jumlah penelitian tentang adiksi smartphone di kalangan pelajar yang sangat terbatas.

\section{DAFTAR PUSTAKA}

Adeyemi, A. M., \& Adeyemi, S. B. (2014). Personal factors as predictors of students academic achievement in colleges of education in South Western Nigeria. Educational Research and Reviews, 9(4), 97-109. doi: 10.5897/ERR2014.1708.

Agusta, D. (2016). Faktor-faktor risiko kecanduan menggunakan smartphone pada siswa di SMK Negeri 1 Kalasan Yogyakarta. Jurnal Riset Mahasiswa Bimbingan Dan Konseling, 5(3), 86-96.

Alavi, S. S., Ferdosi, M., Jannatifard, F., Eslami, M., Alaghemandan, H., \& Setare, M. (2012). Behavioral addiction versus substance addiction: Correspondence of psychiatric and psychological views. International Journal of Preventive Medicine 3(4), 290-294. ISSN: 2008-7802.

Aljomaa, S. S., Qudah, M. F. A., Albursan, I. S., Bakhiet, S. F., \& Abduljabbar, A. S. (2016). Smartphone addiction among university students in the light of some variables. Computers in Human Behavior, 61, 155-164. doi: 10.1016/j. chb.2016.03.041.

Alt, D., \& Boniel-Nissim, M. (2018). Parent-Adoles- 
cent communication and problematic internet use: The mediating role of fear of missing out (FoMO). Journal of Family Issues, 39(13), 33913409. doi: 10.1177/0192513X18783493.

Ayar, D., Bektas, M., Bektas, I., Akdeniz Kudubes, A., Selekoglu Ok, Y., Sal Altan, S., \& Celik, I. (2017). The effect of adolescents' internet addiction on smartphone addiction. Journal of Addictions Nursing, 28(4), 210-214. doi: 10.1097/JAN.0000000000000196.

Broto, G. S. D. (2014). Riset Kominfo dan UNICEF mengenai perilaku anak dan remaja dalam menggunakan internet. Kominfo Siaran Pres. Retrieved from https://kominfo.go.id/index. php/content/detail/3834/.

Cha, S., \& Seo, B. (2018). Smartphone use and smartphone addiction in middle school students in Korea: Prevalence, social networking service, and game use. Health Psychology Open, 5(1), 1-15. doi: 2055102918755046.

Cutino, C. M., \& Nees, M. A. (2017). Restricting mobile phone access during homework increases attainment of study goals. Mobile Media $\mathcal{E}$ Communication, 5(1), 63-79. doi: $10.1177 / 2050157916664558$.

David, P., Kim, J., Brickman, J. S., Ran, W., \& Curtis, C. M. (2015). Mobile phone distraction while studying. New Media E Society, 17(10), 16611679. doi: 10.1177/1461444814531692.

Dewanti, T. C. (2016). Hubungan antara keterampilan sosial dan penggunaan gadget Smartphone dengan prestasi belajar siswa SMA Negeri 9 Malang. Jurnal Kajian Bimbingan dan Konseling, 1(3), 126-131. eISSN: 2503-3417.

Dotterer, A. M., \& Lowe, K. (2011). Classroom context, school engagement, and academic achievement in early adolescence. Journal of Youth and Adolescence, 40(12), 1649-1660. doi: $10.1007 / \mathrm{s} 10964-011-9647-5$.

Frazier, K. (2016). Closing the achievement gap: How do school culture, student satisfaction, and family involvement affect the academic achievement of minority students? (Doctoral Dissertation). ProQuest Dissertations Publishing. (9781339955537, 1339955539). Retrieved from https:// remote-lib.ui.ac.id:2155/ docview /1821366142?pq-origsite=summon.

Granholm, C. (2016). Blended lives: ICT talk among vulnerable young people in Finland. Young, 24(2), 85-101. doi: 10.1177/1103308815613188.

Harvard Health Publishing. (2011). How addiction hijacks the brain. Harvard Health Publishing:
Harvard Medical School, Harvard Mental Health Letter. Retrieved from https://www.health. harvard.edu/newsletter_article/how-addiction-hijacks-the-brain.

Hawi, N. S., \& Samaha, M. (2016). To excel or not to excel: Strong evidence on the adverse effect of smartphone addiction on academic performance. Computers $\mathcal{E}$ Education, 98(7), 81-89. doi: 10.1016/j.compedu.2016.03.007.

Ho, S. S., Lwin, M. O., \& Lee, E. W. J. (2017). Till logout do us part? comparison of factors predicting excessive social network sites use and addiction between Singaporean adolescents and adults. Computers in Human Behavior, 75, 632642. doi: 10.1016/j.chb.2017.06.002.

Internet World Stats. (2018). Top 20 countries with the highest number of Internet users. Internet World Stats: Usage and Population Statistics. Retrieved from https://www.internetworldstats.com/top20.htm.

Jun, W. (2015). An analysis study on correlation of internet addiction and smartphone addiction of teenagers. Paper presented at the 2015 2nd International Conference on Information Science and Security (ICISS). doi: 10.1109/ ICISSEC.2015.7370978.

Junco, R. (2012). Too much face and not enough books: The relationship between multiple indices of Facebook use and academic performance. Computers in Human Behavior, 28(1), 187-198. doi:10.1016/j.chb.2011.08.026.

Juraman, S. R. (2014). Pemanfaatan smartphone android oleh mahasiswa ilmu komunikasi dalam mengakses informasi edukatif. Jurnal Acta Diurna, 3(1), 1-16. Retrieved from https:// ejournal.unsrat.ac.id/index.php/actadiurna/ article/view/4493/4022.

Kibona, L., \& Mgaya, G. (2015). Smartphones' effects on academic performance of higher learning students. Journal of Multidisciplinary Engineering Science and Technology, 2(4), 777784. ISSN: 3159-0040.

Kim, Y., Jang, H. M., Lee, Y., Lee, D., \& Kim, D. (2018). Effects of internet and smartphone addictions on depression and anxiety based on propensity score matching analysis. International Journal of Environmental Research and Public Health, 15(5), 859. doi: 10.3390/ijerph15050859.

Lee, C., \& Lee, S. J. (2017). Prevalence and predictors of smartphone addiction proneness among Korean adolescents. Children and Youth Services Review, 77(6), 10-17. doi: 0.1016/j. 


\section{childyouth.2017.04.002.}

Lee, J., Sung, M., Song, S., Lee, Y., Lee, J., Cho, S., . . Shin, Y. (2018). Psychological factors associated with smartphone addiction in South Korean adolescents. The Journal of Early Adolescence, 38(3), 288-302. doi: 10.1177/0272431616670751.

Lee, Y. K., Chang, C. T., Lin, Y., \& Cheng, Z. H. (2014). The dark side of smartphone usage: Psychological traits, compulsive behavior and technostress. Computers in Human Behavior, 31, 373-383. doi: 10.1016/j.chb.2013.10.047.

Lim, S. A., \& You, S. (2018). Effect of parental negligence on mobile phone dependency among vulnerable social groups: Mediating effect of peer attachment. Psychological Reports, 0(0), 1-13. doi: 0033294118799339.

Liu, D., Kirschner, P. A., \& Karpinski, A. C. (2017). A meta-analysis of the relationship of academic performance and social network site use among adolescents and young adults. Computers in Human Behavior, 77(9), 148-157. doi: 10.1016/j.chb.2017.08.039.

McDonald, N. (2018). Digital in 2018: World's Internet users pass the 4 billion mark. We Are Social: Special Reports. Retrieved from https:// wearesocial.com/us/blog/2018/01/global-digital-report-2018.

McLeod, J. D., Uemura, R., \& Rohrman, S. (2012). Adolescent mental health, behavior problems, and academic achievement. Journal of Health and Social Behavior, 53(4), 482-497. doi: $10.1177 / 0022146512462888$.

Muflih, M., Hamzah, H., \& Purniawan, W. A. (2017). Penggunaan smartphone dan interaksi social pada remaja di SMA Negeri 1 Kalasan, Sleman, Yogyakarta. Idea Nursing Journal, 8(1), 12-18. ISSN: 2087-2879.

Nakaya, A. C. (2014). Internet and social media addiction. Sandiego, CA: ReferencePoint Press.

Oberst, U., Wegmann, E., Stodt, B., Brand, M., \& Chamarro, A. (2017). Negative consequences from heavy social networking in adolescents: The mediating role of fear of missing out. Journal of Adolescence, 55(12), 51-60. doi: 10.1016/j.adolescence.2016.12.008.

Salomon, A., \& Ben-David Kolikant, Y. (2016). Highschool students' perceptions of the effects of non-academic usage of ICT on their academic achievements. Computers in Human Behavior, 64(7), 143-151. doi:10.1016/j.chb.2016.06.024.

Samaha, M., \& Hawi, N. S. (2016). Relationships among smartphone addiction, stress, academic per- formance, and satisfaction with life. Computers in Human Behavior, 57, 321-325. doi: 10.1016/j. chb.2015.12.045.

Sandelowski, M., Barroso, J., \& Voils, C. I. (2007). Using qualitative metasummary to synthesize qualitative and quantitative descriptive findings. Research in Nursing \& Health, 30(1), 99-111. doi: 10.1002/nur.20176.

Schunk, D. H., Pintrich, P. R., \& Meece, J. L. (2012). Motivasi dalam pendidikan: Teori, penelitian, dan aplikasi (Edisi ketiga). Jakarta: PT Indeks.

Seo, D. G., Park, Y., Park, J., \& Kim, M. K. (2016). Mobile phone dependency and its impacts on adolescents' social and academic behaviors. Computers in Human Behavior, 63(5), 282-292. doi: 10.1016/j.chb.2016.05.026.

Sinkkonen, H., Puhakka, H., \& Meriläinen, M. (2014). Internet use and addiction among Finnish adolescents (15-19 years). Journal of Adolescence, 37(2), 123-131. doi: 10.1016/j. adolescence.2013.11.008.

Steinmayr, R., Crede, J., McElvany, N., \& Wirthwein, L. (2016). Subjective well-being, test anxiety, academic achievement: Testing for reciprocal effects. Frontiers in Psychology, 6(1), 1-13. doi: 10.3389/fpsyg.2015.01994.

Tamura, H., Nishida, T., Tsuji, A., \& Sakakibara, H. (2017). Association between excessive use of mobile phone and insomnia and depression among Japanese adolescents. International Journal of Environmental Research and Public Health, 14(7), 701-712. doi: 10.3390/ijerph14070701..

Uzun, A. M., \& Kilis, S. (2019). Does persistent involvement in media and technology lead to lower academic performance? evaluating media and technology use in relation to multitasking, self-regulation and academic performance. Computers in Human Behavior, 90, 196-203. doi: 10.1016/j.chb.2018.08.045.

Van Deursen, A. J., Bolle, C. L., Hegner, S. M., \& Kommers, P. A. (2015). Modeling habitual and addictive smartphone behavior: The role of smartphone usage types, emotional intelligence, social stress, self-regulation, age, and gender. Computers in Human Behavior, 45, 411420. doi: 10.1016/j.chb.2014.12.039.

Wang, P., Wang, X., Wang, X., Wu, Y., Xie, X., Zhao, F., . . Lei, L. (2018). Social networking sites addiction and adolescent depression: A moderated mediation model of rumination and self-esteem. Personality and Individual Differences, 127(2), 162-167. doi: 10.1016/j. 
paid.2018.02.008.

Yi, Y. J., You, S., \& Bae, B. J. (2016). The influence of smartphones on academic performance: The development of the technology-toperformance chain model. Library $\mathrm{Hi}$ Tech, 34(3), 480-499. doi: 10.1108/LHT-042016-0038.

Yun, I., Kim, S., \& Kwon, S. (2016). Low self-control among South Korean adolescents: A test of Gottfredson and Hirschi's generality hypothesis. International Journal of Offender Therapy and Comparative Criminology, 60(10), 1185-1208. doi: 10.1177/0306624X15574683.

Zhang, Y., Qin, X., \& Ren, P. (2018). Adolescents' academic engagement mediates the association between internet addiction and academic achievement: The moderating effect of classroom achievement norm. Computers in $\mathrm{Hu}$ man Behavior, 89(8), 299-307. doi: 10.1016/j. chb.2018.08.018. 
Dampak Negatif Adiksi...

14 PERSPEKTIF Ilmu Pendidikan - Vol. 33 No.1 April 2019 